\title{
Climate Finance Strategy in Morocco
}

\author{
Ezouine Driss $^{1}$ (), Bouaza Naima ${ }^{2}$ \\ ${ }^{1}$ Department of Management, Faculty of Juridical, Economical and Social Sciences University of Mohamed 5, AGDAL, Rabat, \\ Morocco \\ ${ }^{2}$ Department of Management-Faculty of Juridical, Economical and Social Sciences University of Mohamed 5, SOUISSI, Rabat, \\ Morocco \\ Email: ezouinedriss@gmail.com
}

How to cite this paper: Driss, E. and Naima, B. (2019) Climate Finance Strategy in Morocco. American Journal of Climate Change, 8, 482-501. https://doi.org/10.4236/ajcc.2019.84026

Received: November 6, 2019

Accepted: November 15, 2019

Published: November 18, 2019

Copyright (๑) 2019 by author(s) and Scientific Research Publishing Inc. This work is licensed under the Creative Commons Attribution International License (CC BY 4.0).

http://creativecommons.org/licenses/by/4.0/

\begin{abstract}
Climatic events caused a total of 1485 deaths and over 562,000 people affected in Morocco from 1990 to 2014. Climate finance is a key factor in the battle against the effects of global climate change. Morocco for its part is engaged in the process of fight against climate change and has established a sustainable development policy based on renewable energies and has contributed financially to the implementation of several climate projects. In our study, we are proposing a solution to increase the global contribution to climate finance based on global GDP.
\end{abstract}

\section{Keywords}

Climate Change, Climate Finance, Morocco, GDP, Region

\section{Introduction}

Morocco is omnipresent in all framework agreements related to climate change. As a matter of fact, it signed the United Nations Framework Convention on Climate Change (UNFCCC) at the United Nations Conference on Environment and Development (UNCED) in Rio de Janeiro (Brazil) in June 1992 and ratified it on 28 December 1995. In 2001, Morocco held the seventh Conference of the Parties (COP7) in Marrakech to operationalize the 2002 Kyoto Protocol. In November 2016, Morocco again organized the COP22 with the aim of concretizing the new global climate agreement COP21.

Morocco has developed an energy strategy to achieve a $42 \%$ share of the existing capacity from renewable energy sources by 2020 , equitably distributed between solar, wind and water of $2000 \mathrm{MW}$ one. This will save up to $12 \%$ of energy for 2020, and $15 \%$ for 2030. In 2015, the Noor 1 concentrated solar energy (ESC) project was launched in Ouarzazate and it is a thermodynamic solar 
power plant with a capacity of $160 \mathrm{MW}$. The investment is estimated at $\$ 45$ billion (with a national resource estimated at $\$ 10$ billion, provided by Morocco, and dependent on international support in the field of climate finance of 35 billion dollars, see Appendix 2 for financing details). In 2014, Morocco abolished subsidies for fossil fuels, and established a Designated National Authority (DNA) for the Clean Development Mechanism (CDM) in the Kyoto Protocol. Thus, a list of Nationally Appropriate Mitigation Measures (NAMAs) in 2010 sent to the UNFCCC supports the Copenhagen Accord. As a result, it has made its National Determined Intended Contribution (INDC) to the UNFCCC for the new Paris Agreement in 2015 and for its (INDC), Morocco is committed to reduce its GHG emissions by $32 \%$ by $2030^{1}$. The accomplishment of all these projects and commitments requires multilateral financing for the climate given the limited financial resources of Morocco. With investment forecast of US $\$ 15.44$ billion, the energy sector is the most ambitious in terms of reducing greenhouse gas emissions. Morocco's Green Investment Plan focuses on a solar program of at least $\$ 8.3$ billion, and an integrated wind energy program over a 10 -year period; at least $\$ 3.2$ billion has already been advanced. The Green Investment Plan has also adopted a development plan for $400 \mathrm{MW}$ of photovoltaic energy, which will be managed by the National Office of Water and Electricity (ONEE). The investment volume is estimated at nearly $\$ 740$ million. Finally, there is also an energy efficiency program for the industrial sector, with investments estimated at $\$ 184$ million, as well as the subsequent construction of hydroelectric plants, with an estimated investment of $\$ 1.3$ billion. The energy component of the Green Investment Plan alone must reduce $\mathrm{CO}_{2}$ emissions by $147 \mathrm{Mt} \mathrm{CO}_{2}$ equivalent by 2030 .

The transportation sector represents a budget of $\$ 3.7$ billion. For the growing energy needs of cities, the Green Investment Plan proposes a financial mobilization of nearly $\$ 2.8$ billion. This includes the program "Shemsi" of solar water heating $\$ 867$ million and the development program photovoltaic (PV) integrated for the commercial and residential sector $\$ 1.8$ billion not yet validated by the public authorities.

With regard to agriculture, Morocco has developed a Green Investment Plan, entitled "Morocco's Commitment to Combat the Effects of Climate Change", in order to attract private sector investment. It was presented at the World Summit on Climate Change in New York in 2014, on the sidelines of the 69th session ${ }^{2}$ of the United Nations General Assembly, recognizing the voluntary nature of the proactive policy of developing countries, for the protection of the environment and the fight against climate change.

The Green Investment Plan has been prepared with the help of the World Bank and the German Development Cooperation (GIZ). This underlines Mo${ }^{1}$ UNFCCC, 2015. Planned Contribution determined at National level, Morocco. Available on: http://www4.unfccc.int/submissions/INDC/Published\%20Documents/Morocco/1/Maroc\%20CPDN \%20soumise\%20à\%20la\%20CCNUCC\%20-\%205\%20juin\%202015.pdf.

${ }^{2}$ Kingdom of Morocco, 2014. Morocco's commitment in the fight against climate change. Available on: http://www.4c.ma/medias/Plan\%20d'investissement\%20vert\%20VF.pdf. 
rocco's intention to mobilize $\$ 25$ billion, with the aim of achieving a reduction in cumulative greenhouse gas emissions of $181 \mathrm{Mt}$ of $\mathrm{CO}_{2}$ equivalent for the period 2015-2030.

It has 30 investment prospecting projects in the private sector, in 7 areas of mitigation, water, energy, forestry, agriculture, cities, transportation and solid waste management. Agriculture is the fourth sector of financial need that has been budgeted. It is estimated at $\$ 1.2$ billion in order to improve the resilience of Moroccan agricultural production. Financial priorities include a $\$ 61.5$ million solar pumping program for drip irrigation; a project to expand the irrigation area of the Gharb plain estimated at $\$ 645$ million; an irrigation project by desalination of seawater in the Chtouka Ait Baha plain for an estimated budget of \$296 million; a \$105 million conservation and plantation of argan program, a project to reintroduce silvicultural and pastoral practices of $\$ 63.5$ million; lastly, an energy recovery program for olive oil production in the province of Taounate about $\$ 688,000$.

The financial needs of the water sector total $\$ 772$ million. Morocco has opted for a rainwater harvesting program, and a National Rural Sanitation Project (RAN). The first investment of the water sector led to the construction of 10 rainwater collection sites per basin agency, for a total cost of $\$ 2.4$ billion. The RAN, envisages the construction of about 372,000 domestic sanitation systems of \$331 million for 2.23 million inhabitants, and the construction of about 226 collective systems of $\$ 226$ million for about 678,000 inhabitants. In the forestry sector, the forest area has reached 200,000 hectares for $\$ 275$ million, the EcoGharb reforestation project, led by the private operator Planetic and supported by the local community, with the basin areas and the slopes of the dams upstream with a budget of $\$ 42.5$ million. Finally, the Green Investment Plan puts forward a single waste management project, namely the valuation of greenhouse gas emissions from landfills, for $\$ 226$ million.

To assist Morocco to implement the Competence Center for Climate Change (4C Morocco) see Figure 1, the German Federal Ministry of the Environment (BMU) in the framework of the International Climate Initiative (ICI) with a total budget of $€ 2$ million $^{3}$, the German bilateral climate fund through its unit La GIZ, a German international cooperation company, focused on the environment and climate change, cooperates in partnership with the National Observatory of the Environment.

The 4C Morocco International Climate Initiative project aims to improve Morocco's overall adaptation capacity and reduce GHG emissions. The 4 CMorocco project is a platform for capacity building for actors from different sectors, whether public or private, local or regional, in collaboration with civil society and involving training and research.

In this paper we shall discuss the topic of global climate finance (with a global scheme) see Appendix 1 but we will focus more on Morocco which is widely recognized as a world leader for its commitments especially in renewable ${ }^{3}$ https://www.giz.de/en/worldwide/27018.html. 


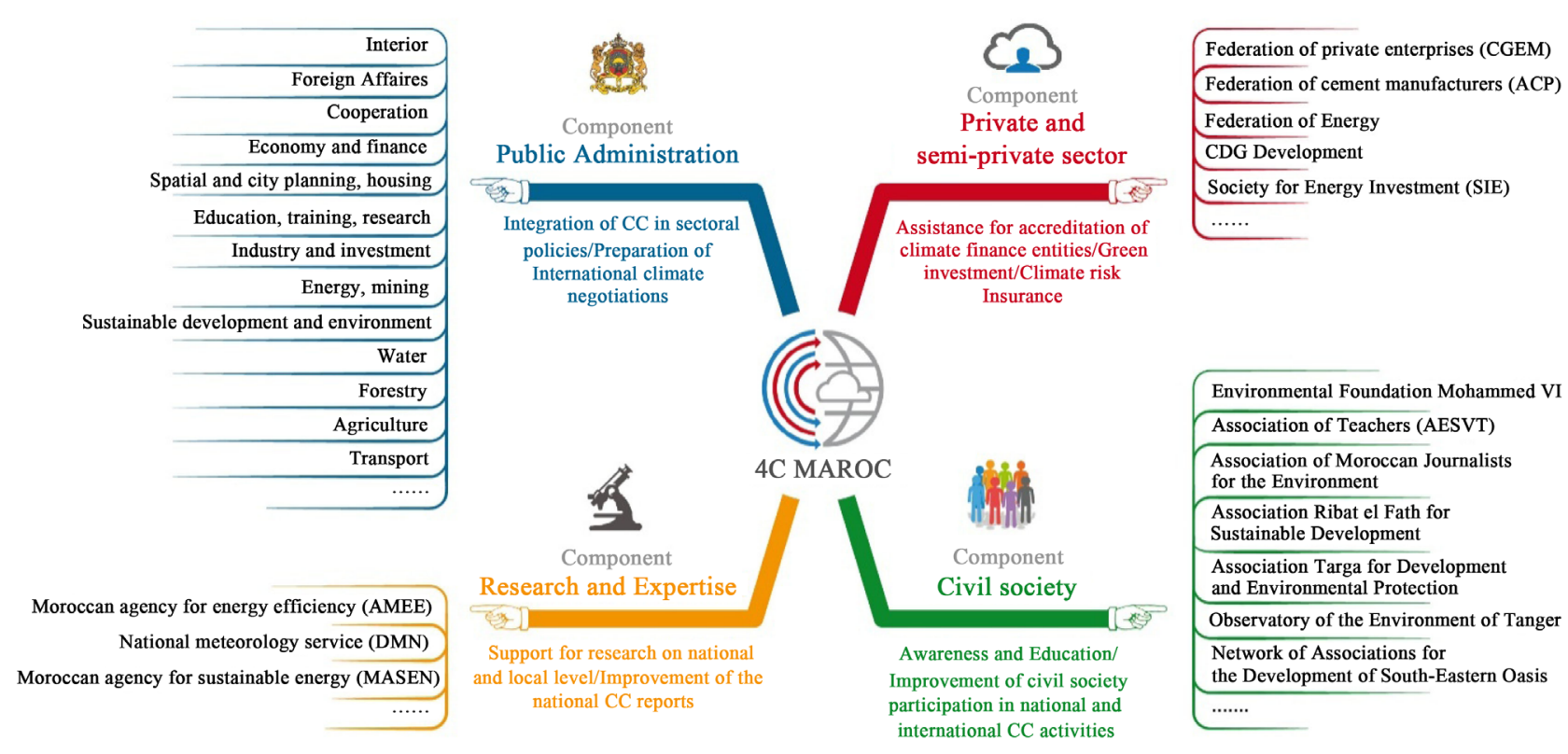

Figure 1. Heuristic map of the Competence Center for Climate Change of Morocco (4C Morocc). Source: https://www.giz.de/en/downloads/giz2015-en-mind-map-4c-morocco.pdf.

energies. The analysis provides an overview of how climate finance is being administered and implemented.

The 4th Assessment Report of the Intergovernmental Panel on Climate Change (IPCC) identifies Morocco as a country highly vulnerable to climate change. The $93 \%$ of the land is subject to an arid or semi-arid climate. Overall, precipitation has shown a high degree of variability and a downward trend $(-3 \%$ to $-30 \%$ ) over the period 1976-2006. There has been a significant change in temperature: average temperature rises have affected the whole country (with an average increase of $1^{\circ} \mathrm{C}$ in two-thirds of the Moroccan territory and a maximum annual average increase of $1.4^{\circ} \mathrm{C}$ in the south-east of the country). Since the 1960s, we have also noticed that: Drought has become a more common phenomenon. In 2050, evapotranspiration in the northern Sahara will increase from $105 \%$ to $110 \%{ }^{4}$. The Atlantic plains and the foothills of the Atlas will probably experience the largest decrease in precipitation, likely to reach $60 \%$ after $2071^{5}$. Two-thirds of Moroccan beaches are already threatened by erosion and the risk of storms along the coast increases ${ }^{6}$.

\section{Literature Review}

Climate change has a negative impact on the global evolution of the international economy the thing that has been shown in several studies see: Kompas, T., ${ }^{4}[$ CCNUCC, 2010. Seconde Communication Nationale à la Convention-Cadre des Nations Unies sur les Changements Climatiques. Département du Développement Territorial, de l'Urbanisme, de l'Habitat et de l'Environnement, Royaume du Maroc.

${ }^{5}$ Direction de la Météorologie Nationale, 2007.

${ }^{6}$ CCNUCC, 2016. Troisième Communication Nationale à la Convention des Nations unies sur les changements climatiques. Ministère délégué à l'Énergie, aux Mines, à l'Eau et à l'Environnement, Maroc. 
Pham, V. H., \& Che, T. N. (2018) [1] showed by economic modeling covering 139 countries and 57 major product groups (broad commodity groups) consistent with the Paris Climate Agreement that the overall gains from compliance with the $2^{\circ} \mathrm{C}$ target are approximately $\$ 17,489$ billion per year over the long-term (2100) another result of the same study shows that the scenario of global warming of $3^{\circ} \mathrm{C}$ will have a negative impact on Morocco's GDP of around -0.200 by 2027 and -2.436 in the long term. Then in the G20 note [2] the application of climate-compatible policies compared to maintaining current policies, can increase GDP by $2.8 \%$ on average by 2050 in the developed and emerging economies of the G20 and the net effect on GDP by 2050 almost 5\%, taking into account the positive effects of prevention against climate change. In the report (IPCC) [3] Climate change is a threat to sustainable development. Alice Pauthier [4] initiates the origin of climate finance as a need a means at the same time to act against climate change. Another study carried out jointly by (UNEP FI) and (BMZ) [5] analyzes the role of public authorities in determining how public finances and policies can be used to catalyze private investment in adaptation. Jon Strand [6] proposes the model countries to integrate a climate treaty with two options. Stephen Hall study, Katy E. Roelich, Mark E. Davis and Lars Holstenkamp [7] discusses the relationship between finance and energy and estimates the amount of global investment needed to decarbonize the sector to $\$ 61$ trillion to limit global warming at 2 degrees Celsius. Julian E. Salt [8] wonders only about the rate of climate change. Peterson Molina Vale [9] estimates the age of the climate change economy at 40and proposes an improvement of the standard model based on the modeling of the social cost of carbon. William Nordhaus [10] publishes its work on the economics of climate change in (1975), during these 40 years economists have tried integrated valuation modeling. William Cline [11] published The Global Warming Economy; Stern [12] in (2006) asks technical questions like intertemporal discount and in (2013) [13] proposes economic models of the impact of climate change; Di Falco [14], proposes a new result more complete. William Nordhaus [10] 2008 provides the unique model containing all the links between carbon dioxide concentrations, climate, economic damage caused by climate change called the Dynamic Integrated Model of Climate and Economy (DICE). Stainforth et al. [15] (2007), pronounces that modeling uncertainty is a serious challenge to include uncertainty in modeling the economics of climate change is relatively recent, Weitzman [16] (2007), Kolstad [17] (1994); Tsur \& Zemel [18] (1996) and Gjerde et al. [19] (1999) Vale [20], (2010). Nordhaus [10], (2008) proposes an internationally harmonized carbon tax to mitigate the effects of climate change, Weitzman [21], (2013) gives an alternative to fiscal policy that of the cap-and-trade agreement. Both policies have been criticized for imposing more distortions and delivering dubious results in Europe. Both of these policies have been criticized for imposing more distortions and delivering dubious results in Europe see (Giddens [22], 2009). Boteti \& Victor [23], (2011) stresses that carbon pricing systems are not coordinated at the global level. McKibbin et al. [24] (2011), proclaims a harmonized tax, whereas 
Green [25], (2014); Helm [26], (2012); Weitzman [21], (2013) discusses the political weight of the signatory leaders of the agreements. Bosetti \& Victor, (2011) Criticism of carbon pricing systems is not internationally coordinated and emission reduction results are low, hence the need for a harmonized tax that seems impractical McKibbin et al. [24] (2011), in the same context the Copenhagen summit opened the political way for countries to take unilateral mitigation measures. Hallegatte et al. [27], (2011) finds that most research and economic studies underestimate the role of families, businesses and communities in contributing to the development of solutions to climate change, but this is beginning to change as adaptation has moved into the UNFCCC agenda through the Adaptation Fund, the Green Fund and the National Adaptation Plans, Fankhauser \& Burton, [28] (2011) also the editorial of Nature Climate changes [29], (2013) proposes a coexistence with these climatic changes by developing solutions in this direction. Antweiler [30], (2011) However, it depends mainly on the relative costs as well as the complementarity between adaptation and mitigation. For a sufficiently high cost for adaptation, Buob \& Gunter [31] (2011) find that poor countries will only engage in mitigation even without cooperative behavior. Marrouchet Chaudhuri [32], (2011). Adaptation can bring an advantage of political legitimacy. Ayers \& Forsyth, [33] (2009); Ayers \& Dodman [34], (2010), raise the idea of "adaptation as development" in political ecology and Fankhauser, (2010) [35], (2014) [36]) proposes this notion in an economic context whereas, Di Falco et al. [37] (2011) have found a causal link between climate change adaptation and food security in a study of agriculture in Ethiopia. Di Falco \& Veronesi [38], (2013) propose more effective coping strategies by acting in conjunction with other practices such as water conservation methods. Adaptation is at the center of climate policy debates Petherick [39], (2012). Most of the work is on agriculture Hertel \& Lobell [40], (2014) provide a current synthesis of the literature, De Zeeuw \& Zemel [41], (2012); Zemel [42], (2015) assume that adaptation fits into politics to deal with global warming. David Castells-Quintana, Maria del Pilar Lopez-Uribe, Thomas K.J. McDermott [43] Discuss access to (formal) financial services through credits that can improve optimal adaptation, Cai, Chen, Fang \& Zhou [44], (2009); Galarza \& Carter [45], (2011); Hill \& Viceisza [46], (2012); Mobarak \& Rosenzweig [47], (2013). Other work has shown the link between improved access to finance to fight poverty and adaptation to climate change Hecht [48], (2008); Ward, Herweijer, Patmore Muir-Wood, [49] (2010); MCII, [50] (2012), MCII, [51] (2013). But it is not easy for poor and vulnerable families hence the role of microfinance that can do the trick Agrawala \& Carraro, [52] (2010); World Bank, [53] (2013) and to reach a large clientele King, [54] (2012) proposes communications technology as a tool.

\section{Data and Empirical Results}

Table 1 shows the different climatic events that occurred in Morocco between the period of 1995 and 2014 causing a total of 1485 deaths and over 562,000 people affected. 
Table 1. Main extreme (climatic) events in Morocco from 1990 to 2014.

\begin{tabular}{cccc}
\hline Event type & Year & Number of deaths & Total number of people affected \\
\hline Storm & 2014 & 47 & 117000 \\
Flood & 2014 & & 75000 \\
Flood & 2010 & 628 & \\
Earthquake & 2004 & 80 & 275000 \\
Flood & 2002 & & 60000 \\
Drought & 1999 & & 35000 \\
Flood & 1996 & & \\
Flood & 1995 & 730 & \\
Flood & 1995 & & \\
\hline
\end{tabular}

Sources: EM-DAT, 2015; World Bank, 2015; Davies, 2014.

According to Figure 2, we note that electricity production leads the way in $\mathrm{CO}_{2}$ emissions with $25 \%$ followed by agriculture, industry and transport, only these four sectors capitalize more than $84 \%$ of $\mathrm{CO}_{2}$ emission which requires urgent intervention to change the situation.

According to Figure 3, we can clearly see that the industrialized countries (China, USA, EU, India, Russia and Japan) emit more than $70 \%$ of the total world $\mathrm{CO}_{2}$ volume, which implies, ethically and legally, these countries to engage more and more in climate finance in order to limit the negative effects of $\mathrm{CO}_{2}$.

According to Figure 4, we can conclude that the evolution of $\mathrm{CO}_{2}$ emissions in the forestry, waste and industrial processes sector is negligible compared to the agriculture and energy sector, rising from 51,099 in 2010 to 138,880 in 2040 what presents more than $271 \%$ which is alarming and requires the intervention of Morocco.

Figure 5 gives us the sources of energy consumption in Morocco, over $84 \%$ is thermal which and push Morocco to make more efforts in developing hydro and wind energy.

Morocco is very fragile to the effects of climate change and is less dependent on official development assistance (ODA) than many other African countries. Concessional development assistance is in the order of $1 \%$ of GDP, with inflows accounting for some $\$ 2.247$ billion, or $\$ 66.20$ per capita in 2014 , with substantial loans granted by the African Development Bank (AfDB), the World Bank (WB) and the European Investment Bank (EIB $)^{7}$. In this context, global climate finance flows in Morocco is focused on supporting medium- and large-scale solar and wind projects that could not succeed without considerable public support ${ }^{8}$. It appears in Figure 6 that Morocco benefited greatly from public funds dedicated ${ }^{7}$ http://www.oecd.org/statistics/datalab/oda-recipient-sector.htm.

${ }^{8}$ Germanwatch, 2016. MENA-SELECT, abstract: Fiche d'informations sur le Maroc. Énergie et développement en un coup d'œil, 2016. To read on:

https://germanwatch.org/sites/germanwatch.org/files/publication/11700.pdf. 


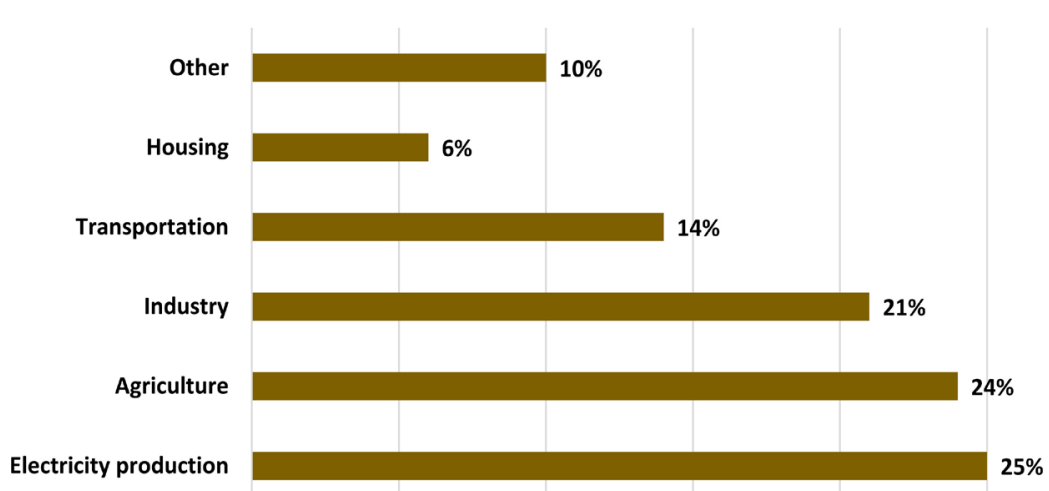

Figure 2. $\mathrm{CO}_{2}$ emissions in Morocco in 2012 and the share of each sector by sector of activity. Source: https://www.statista.com/ (US Environmental Protection Agency (EPA)).

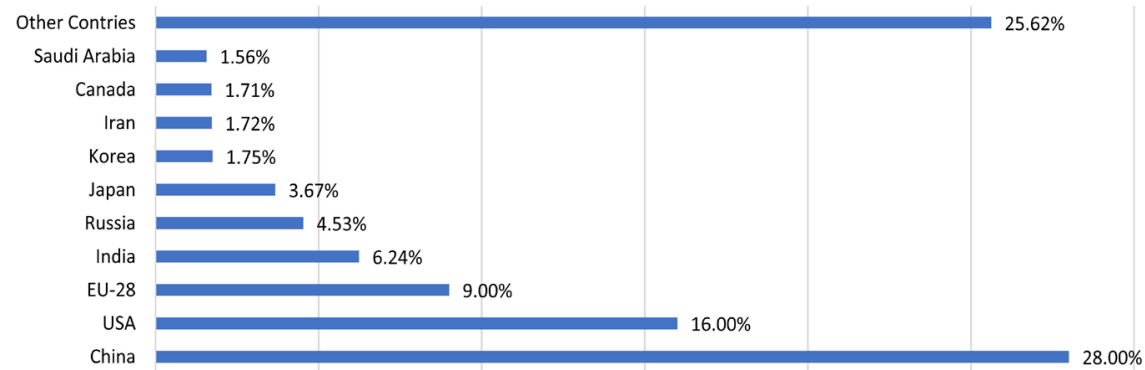

Figure 3. Countries with the highest $\mathrm{CO}_{2}$ emissions from energy combustion. Source: www.statista.com (US Environmental Protection Agency (EPA)).

300000

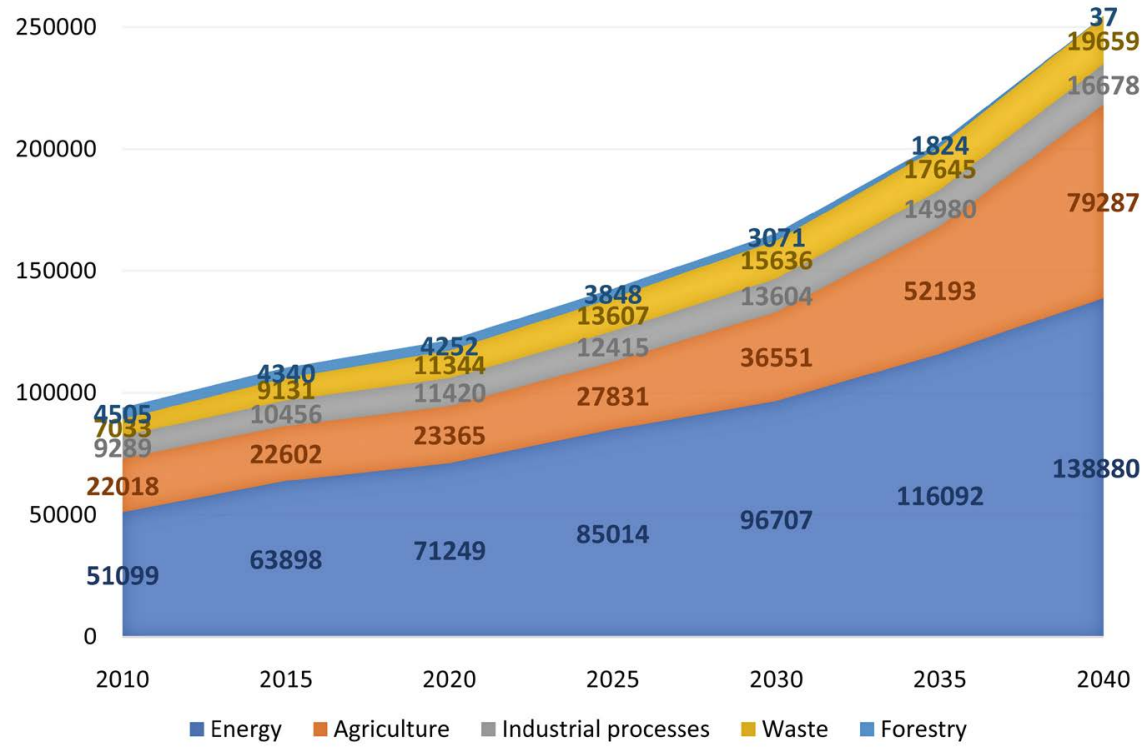

Figure 4. Projections of GHG emissions trends by sector (2010-2040, baseline). Source: United Nations Framework Convention on Climate Change (UNFCCC), 2016. Third National Communication to the United Nations Convention on Climate Change. Delegated Ministry of Energy, Mines, Water and Environment, Morocco, 2016. 


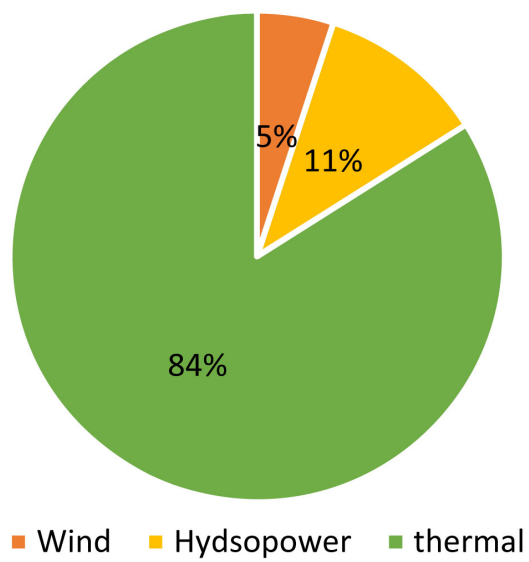

Figure 5. Sources of energy consumption in Morocco. Source: MEMEE, Department of Energy and Mines, 2011.

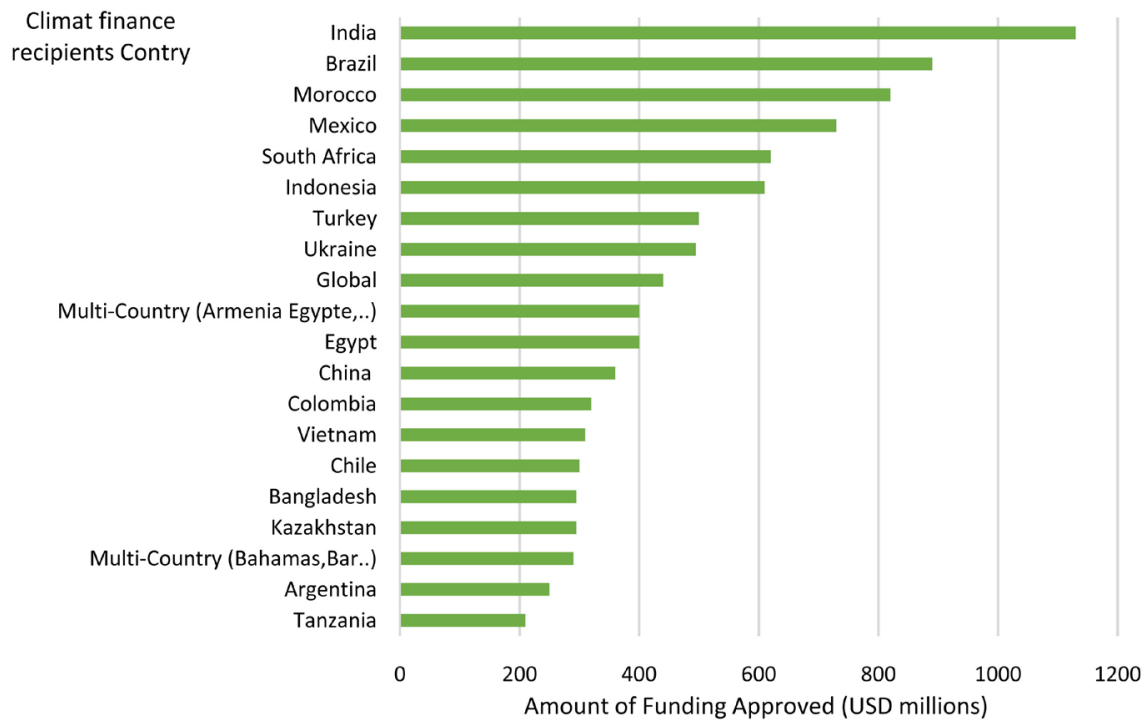

Figure 6. The beneficiaries of climate finance. Source:

https://public.tableau.com/profile/gbanton\#!/vizhome/CFU-Climatefinancerecipients/Re cipients.

to a global level. Nevertheless, Morocco's efforts to adapt to the international scale remain insufficient, see Figure 9.

Figure 6 gives us an idea of the most supported countries of climate finance because we find that Morocco comes in 3rd place behind India and Brazil with more than $\$ 800$ million.

We see in Figure 7 that is the most loans granted to Morocco are in the form of concessional loans while grants are almost negligible \$25 million the thing that is reversed compared to Brazil because almost $\$ 600$ million are form of subsidies.

Figure 8 gives us a comparison between the amounts approved by the climate funds to Morocco and those actually disbursed. During the period 2007 to 2017 only $61.14 \%$ of the amounts are disbursed of a total of $\$ 783.96$ million approved. 


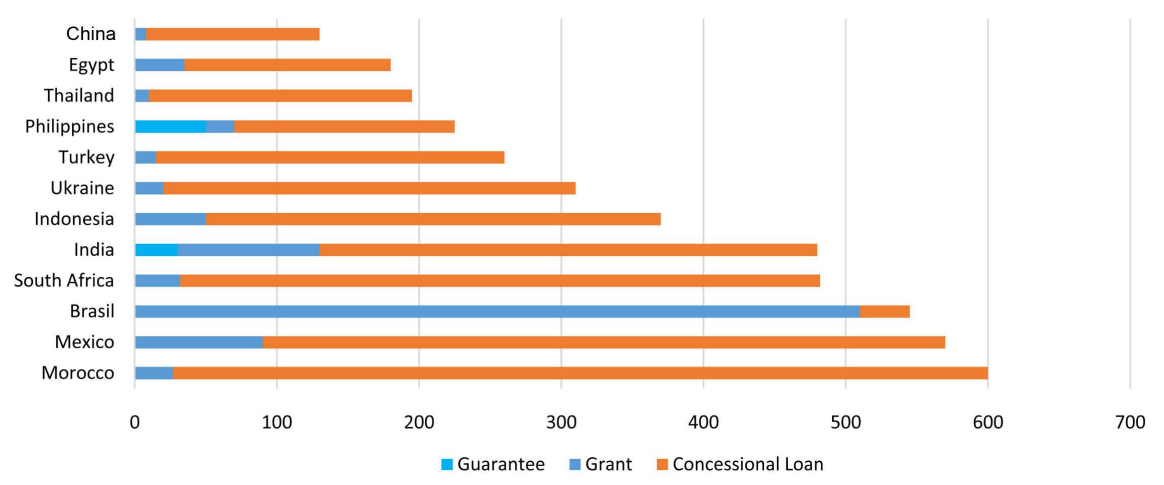

Figure 7. In what form do they receive their funds? Source: https://public.tableau.com/profile/gbanton\#!/vizhome/CFU-Climatefinancerecipients/Re cipients.

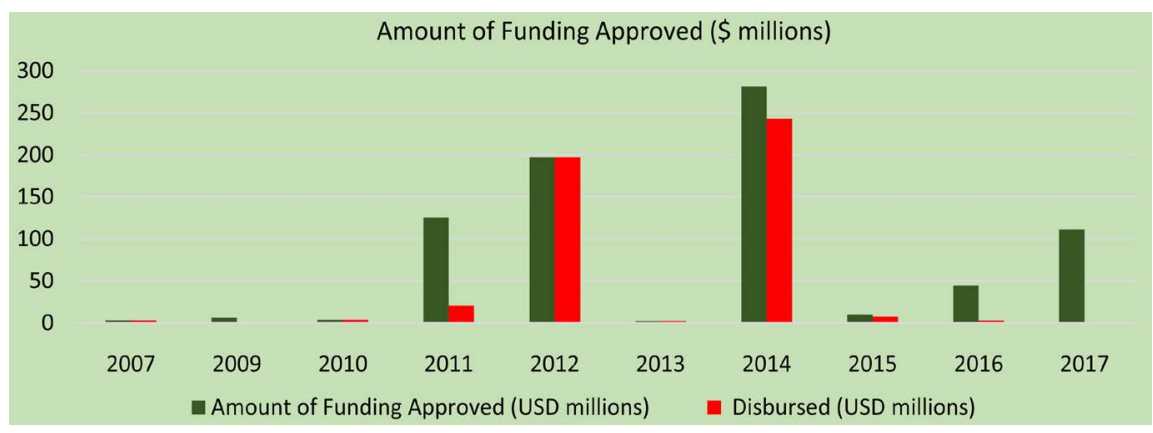

Figure 8. Amount of financing approved to Morocco (\$millions). Source: figure drawn up by us based on the data of CFU:

(https://public.tableau.com/profile/gbanton\#!/vizhome/CFU-Climatefinancerecipients/Re cipients) data on Appendix 3.

Figure 9 presents the segmentation of climate finance in Morocco by domain with $95 \%$ for mitigation $4 \%$ for Adaption.

Figure 10 explains to what extent Africa is involved in the fight against global warming with South Africa leading by 16 projects and Morocco in 8th place by 10 projects including 5 energy efficient technologies, most of projects are of type (Capacity building) as we can notice with the yellow color which dominates the figure.

In Figure 11 we have summed the GDP of all countries for the period from 2010 to 2016 and we have taken a percentage of the total GDP for everyone and we have varied the rate from $0.001 \%$ to $1 \%$ that gives us a huge possibility of climate financing which at $0.001 \%$ reached $\$ 4246,154,915$ and $1 \%$ we will reach a record $\$ 424,615,491,599$.

The countries presented in the figure are all countries (total of 264) where their GDP appears in the World Bank website (https://data.worldbank.org/indicator/NY.GDP.MKTP.CD).

Focusing on Morocco in Figure 12 and using the same logic in Figure 11, we will have $\$ 10,083,042.43$ for $0.01 \%$ of GDP while this amount is $\$ 1,008,304$ 243.48 for $1 \%$. 


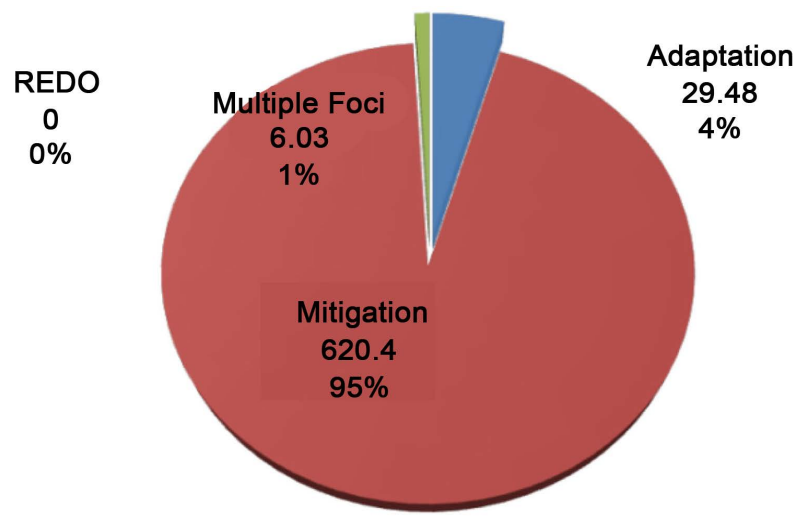

Figure 9. Morocco's international climate financing by domain (\$ millions). Source: Climate Funds Update (CFU), September 2016, https://climatefundsupdate.org/data-dashboard/.

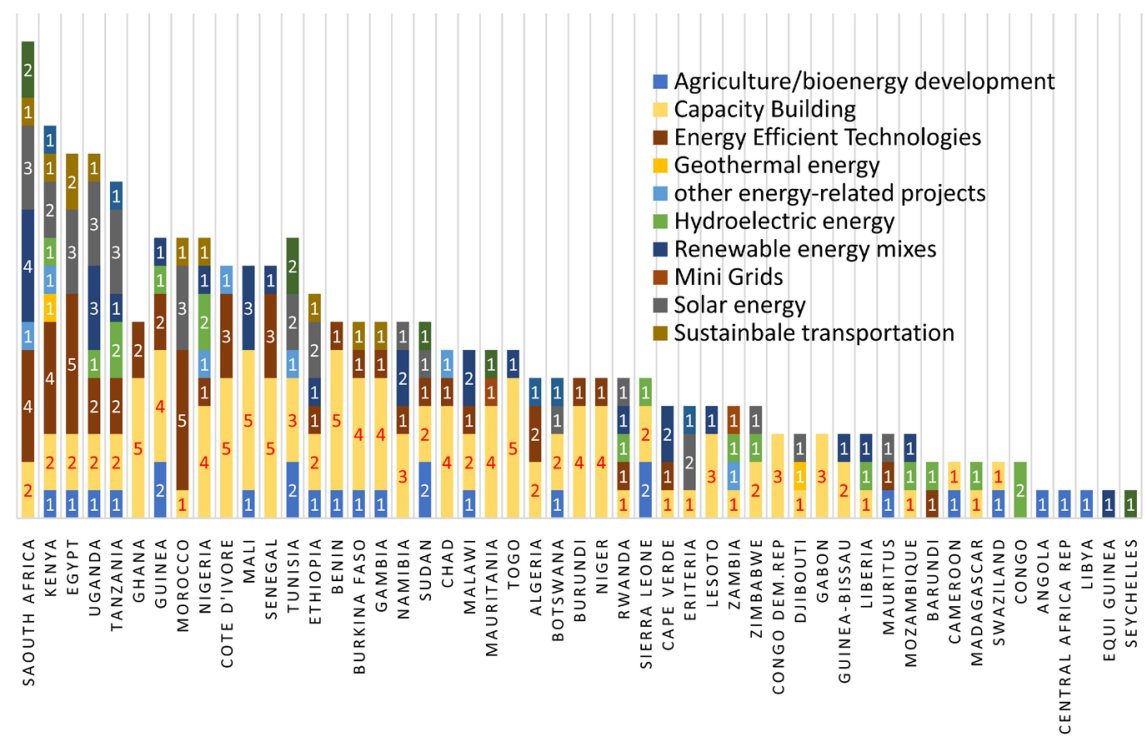

Figure 10. Number of global environmental facility mitigation projects by African country. Source: Mitigating Climate Change in Africa ${ }^{9}$.

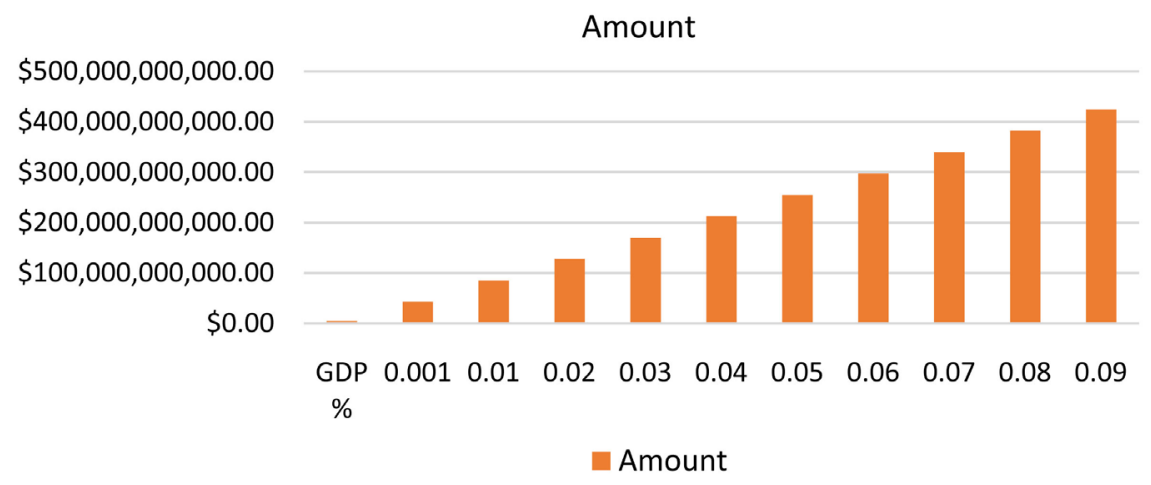

Figure 11. Climate finance hypothesis by varying the rate of GDP to retain. Source: figure drawn up by us based on the World Bank.

${ }^{9}$ Mitigating Climate Change in Africa: Barriers to Financing Low-Carbon Development Ademola A. Adenle, Dale T. Manning, Joseph Arbiol. 


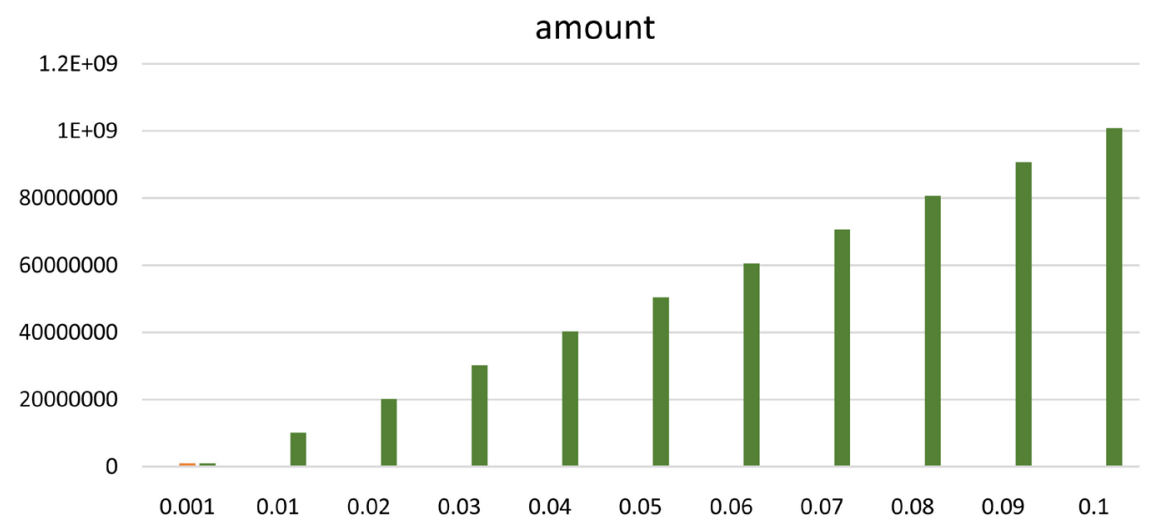

Figure 12. Climate finance hypothesis by varying the rate of GDP case of Morocco. Source: figure drawn up by us based on the High Commission for planning site (https://www.hcp.ma).

In Figure 13, we have applied the same principle to the global finance of the world GDP of each region in Morocco and we can see that $0.01 \%$ of the GDP of the region, Casablanca comes first by $\$ 1,714,036.80$ and $\$ 1,714,036,800.08$ to $1 \%$ which presents a very important liant in order to finance the climate projects of the region, certainly the other regions will have less financial sources because they have a lower GDP than that of Casablanca so they produce less $\mathrm{CO}_{2}$.

Figure 14 clearly shows the relationship between GDP and $\mathrm{CO}_{2}$ emissions (positive correlation) which justifies the idea of financing the climate by an equal percentage of the GDP which makes fair contribution to pollution.

Morocco's trade balance is unbalanced in 1998. The deficit was at least 2.1 million dollars while in 2017 it reached 16.2 million dollars for sever almost important factor is energy costs. The pick observed in 2008 is related to the impact of the international financial crisis of same year on international trade (Figure 15).

Figure 16 shows the importance of agriculture in the Moroccan economy reaching up to $20 \%$ GDP of the country in 1996 . On the other hand, we can notice the stochastic form of the graph following its connection to the rain. In recent years the rate begins to fold following the improvement of the automotive and aerospace industries as well as the service sector and offshoring.

\section{Conclusions}

In order to face the global warming and other environmental problems, a low-carbon economy has become the common choice of the world. Morocco, in turn, attaches great importance to global climate change and has become an important practitioner of the low-carbon economy with several projects mainly in renewable energy and agriculture. We put forward an important idea to finance the climate from the global GDP of each country with a percentage equal to everyone because the one who produces more pollutes more is therefore to contribute more. 

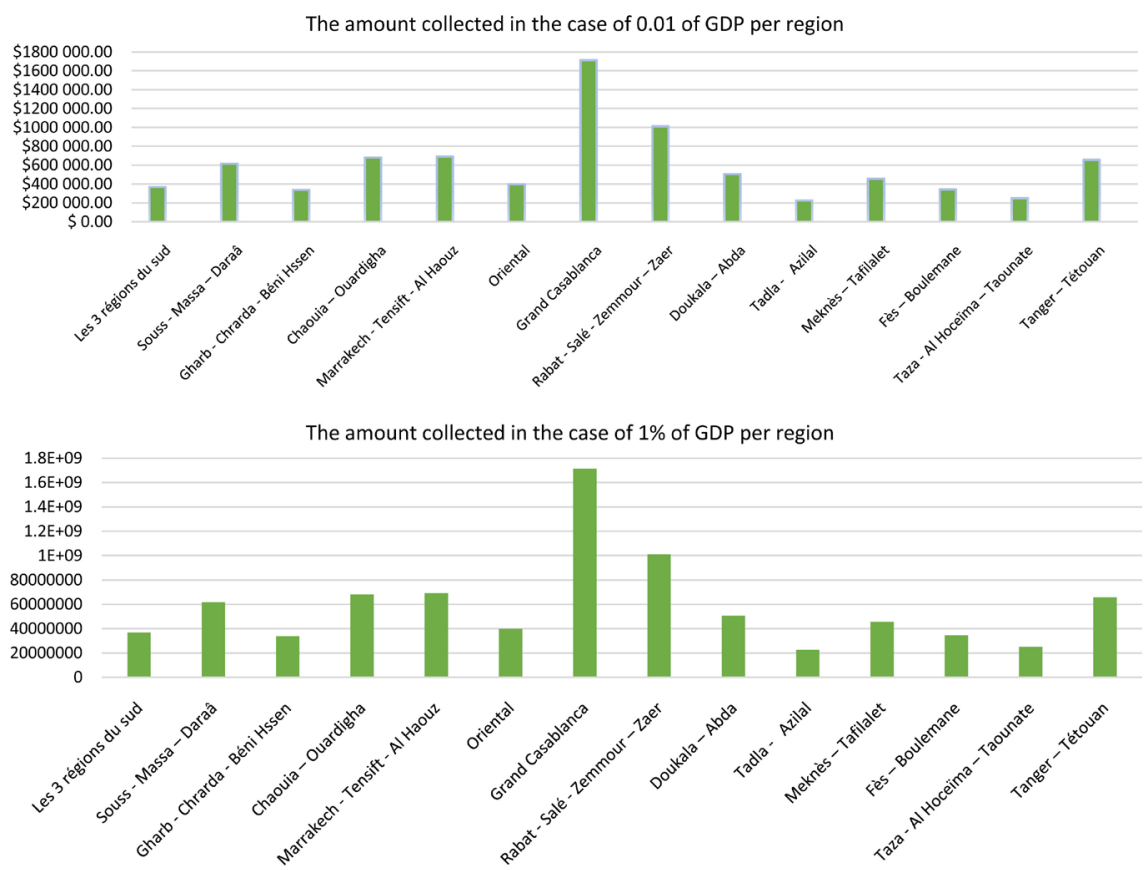

Figure 13. Climate finance hypothesis by varying the rate of GDP per region case of Morocco. Source: figure drawn up by us based on the High Commission for planning site (https://www.hcp.ma).
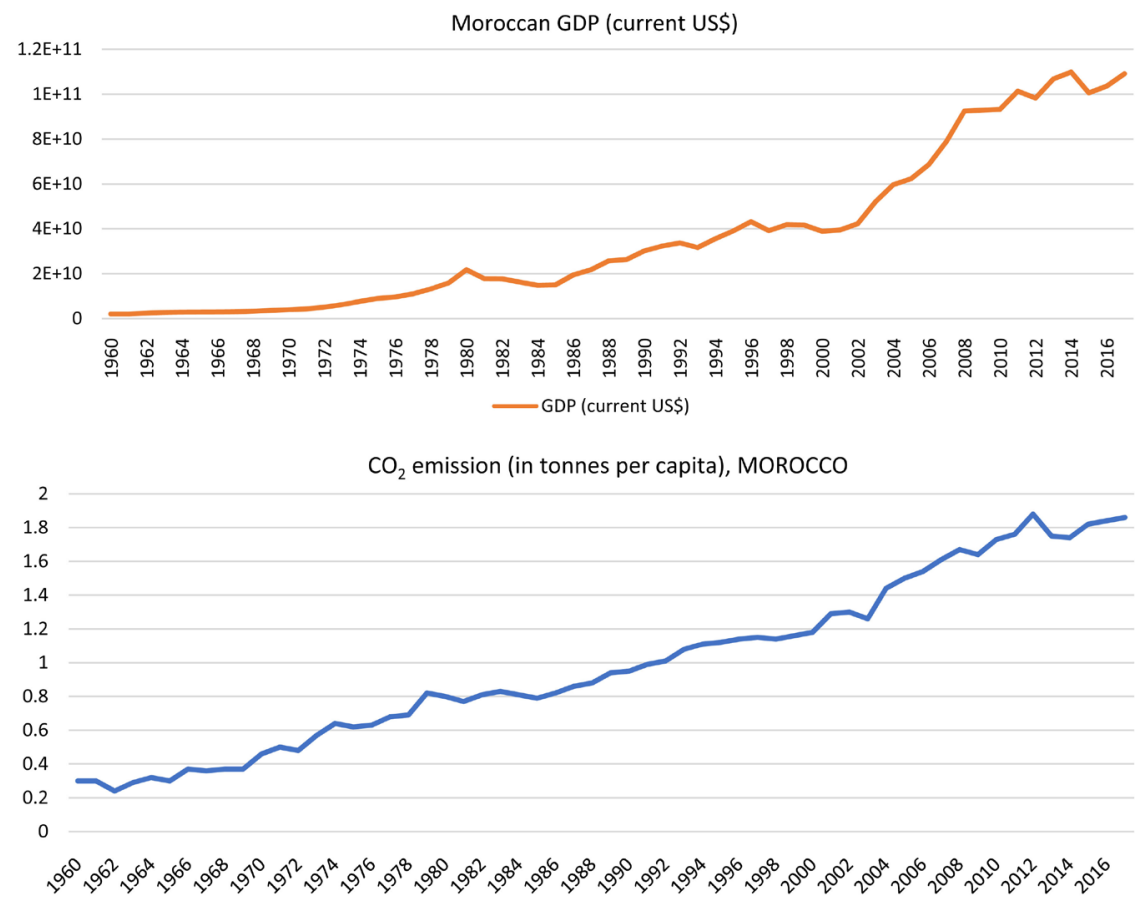

Figure 14. The relation between Moroccan GDP and $\mathrm{CO}_{2}$ emission. Figure prepared by us based on World Bank data.

Morocco's vision for advanced regionalization must provide regional authorities with financial sources for climate and applying this hypothesis in each region will have a fund to carry out its own projects. 


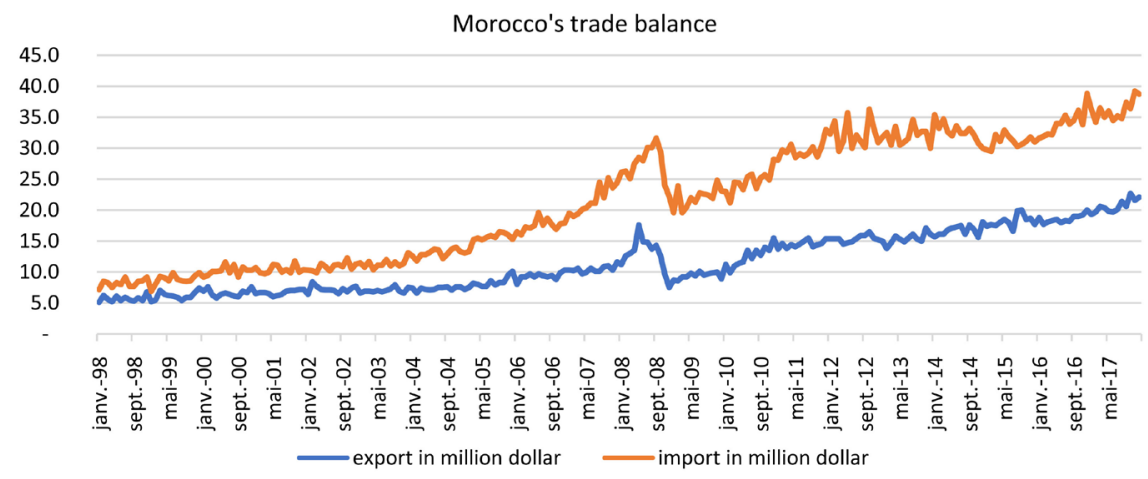

Figure 15. Morocco's trade balance. Source: figure established by us date from https://www.oc.gov.ma/fr/etudes-et-statistiques/series-statistiques.

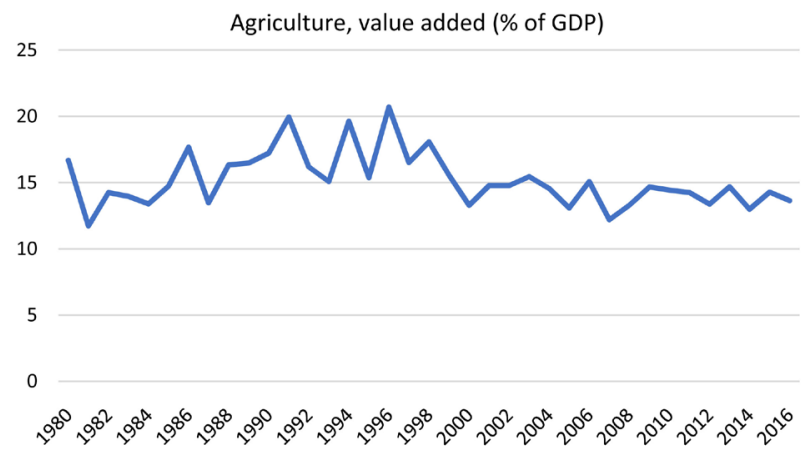

Figure 16. Agriculture, value added. Source: figure established by us date from https://www.oc.gov.ma/fr/etudes-et-statistiques/series-statistiques.

Finally, the relationship between the GDP and the $\mathrm{CO}_{2}$ emission has been shown which gives support to the hypothesis of financing the climate by GDP. Morocco is the third country supported by the climate after India and Brazil.

\section{Conflicts of Interest}

The authors declare no conflicts of interest regarding the publication of this paper.

\section{References}

[1] Kompas, T., Pham, V.H. and Che, T.N. (2018) The Effects of Climate Change on GDP by Country and the Global Economic Gains from Complying with the Paris Climate Accord. Earth's Future, 6, 1153-1173. https://doi.org/10.1029/2018EF000922

[2] OCDE (2017) La note Investing in Climate, Investing in Growth a été préparé par l'OCDE dans le cadre de la présidence allemande du G20.

[3] IPCC (2018) Summary for Policymakers Intergovernmental Panel on Climate Change (IPCC) The Synthesis Report Includes Information Related to Article 2 of the United Nations Framework Convention on Climate Change (UNFCCC).

[4] Pauthier, A. (2016) Finance Et Climat, Quels Enjeux? Institut de relations internationales et stratégiques.

[5] UNEP Finance Initiative (UNEP FI), the German Federal Ministry for Economic 
Cooperation and Development (BMZ), the German Development Corporation (GIZ), the Frankfurt School UNEP Collaborating Centre for Climate \& Sustainable Energy Finance, The German Development Centre (DIE) and Acclimatize (2016) Demystifying Adaptation Finance for the Private Sector.

[6] Strand, J. (2016) Mitigation Incentives with Climate Finance and Treaty Options.

[7] Hall, S., Roelich, K.E., Davis, M.E. and Holstenkamp, L. (2018) Finance and Justice in Low-Carbon Energy Transitions. Applied Energy, 222, 772-780.

[8] Julian, E. (2001) Salt Climate Change and the Insurance Industry.

[9] Molina Vale, P. (2016) The Changing Climate of Climate Change Economics. Ecological Economics, 121, 12-19.

[10] Nordhaus, W. (2008) A Question of Balance: Weighing the Options on Global Warming Policies. Yale University Press, New Haven, CT.

[11] Cline, W. (2008) L'économie du réchauffement planétaire. Finances \& Développement.

[12] Stern, N. (2006) Stern Review: The Economics of Climate Change. HM Treasury London, London. https://doi.org/10.1017/CBO9780511817434

[13] Stern, N. (2013) The Structure of Economic Modeling of the Potential Impacts of Climate Change: Grafting Gross Underestimation of Risk Onto Already Narrow Science Models. Journal of Economic Literature, 51, 838-859. https://doi.org/10.1257/jel.51.3.838

[14] Di Falco, S. (2014) Adaptation to Climate Change in Sub-Saharan Agriculture: Assessing the Evidence and Rethinking the Drivers. European Review of Agricultural Economics, 41, 405-430. https://doi.org/10.1093/erae/jbu014

[15] Stainforth, D., Allen, M., Tredger, E. and Smith, L. (2007) Confidence, Uncertainty and Decision Support Relevance in Climate Predictions. Philosophical Transactions of the Royal Society A: Mathematical, Physical and Engineering Sciences, 365, 2145-2161. https://doi.org/10.1098/rsta.2007.2074

[16] Weitzman, M. (2007) Role of Uncertainty in the Economics of Catastrophic Climate Change. AEI-Brookings Joint Center Working Paper.

[17] Kolstad, C. (1994) George Bush versus Al Gore: Irreversibilities in Greenhouse Gas Accumulation and Emission Control Investment. Energy Policy, 22, 771-778. https://doi.org/10.1016/0301-4215(94)90053-1

[18] Tsur, Y. and Zemel, A. (1996) Accounting for Global Warming Risks: Resource Management under Event Uncertainty. Journal of Economic Dynamics and Control, 20, 1289-1305. https://doi.org/10.1016/0165-1889(95)00900-0

[19] Gjerde, J., Grepperud, S. and Kverndokk, S. (1999) Optimal Climate Policy under the Possibility of a Catastrophe. Resource and Energy Economics, 21, 289-317. https://doi.org/10.1016/S0928-7655(99)00006-8

[20] Vale, P.M. (2010) Economia das mudançasclimáticas: Umaavaliação dos principaismodelos. Master's Dissertation, Economics Institute, UNICAMP, Brazil.

[21] Weitzman, M. (2013) Can Negotiating a Uniform Carbon Price.

[22] Giddens, A. (2009) The Politics of Climate Change. Polity, Cambridge, UK.

[23] Bosetti, V. and Victor, D. (2011) Politics and Economics of Second-Best Regulation of Greenhouse Gases: The Importance of Regulatory Credibility. The Energy Journal, 32, 1-24. https://doi.org/10.5547/ISSN0195-6574-EJ-Vol32-No1-1

[24] McKibbin, W., Morris, A. and Wilcoxen, P. (2011) Comparing Climate Commitments: A Model Based Analysis of the Copenhagen Accord. Climate Change Eco- 
nomics, 2, 79-103. https://doi.org/10.1142/S201000781100022X

[25] Green, F. (2014) “This Time It's Different”: The Prospects for an Effective Climate Agreement in Paris 2015. Grantham Research Institute on Climate Change and the Environment Policy Paper. London School of Economics, London, UK.

[26] Helm, D. (2012) Crunch, Carbon, 2012. The Carbon Crunch. Yale University Press. New Haven, CT. https://doi.org/10.12987/yale/9780300186598.001.0001

[27] Hallegatte, S., Lecocq, F. and De Perthuis, C. (2011) Designing Climate Change Adaptation Policies: An Economic Framework. World Bank Policy Research Working Paper.

[28] Fankhauser, S. and Burton, I. (2011) Spending Adaptation Money Wisely. Climate Policy, 11, 1037-1049. https://doi.org/10.1080/14693062.2011.582389

[29] Editorial de Nature Climate Change (2013) https://www.nature.com/nclimate/articles?type=editorial

[30] Antweiler, W. (2011) Mitigation + Adaptation: What Is the Optimal Climate Change Policy Mix. University of British Columbia, British Columbia. https://doi.org/10.2139/ssrn.1802857

[31] Buob, S. and Gunter, S. (2011) To Mitigate or to Adapt: How to Confront Global Climate Change. European Journal of Political Economy, 27, 1-16. https://doi.org/10.1016/j.ejpoleco.2010.05.001

[32] Marrouch, W. and Chaudhuri, A. (2011) International Environmental Agreements in the Presence of Adaptation. FEEM Working Paper No. 35. https://doi.org/10.2139/ssrn.1824162

[33] Ayers, J. and Forsyth, T. (2009) Community-Based Adaptation to Climate Change. Environment, 51, 22-31. https://doi.org/10.3200/ENV.51.4.22-31

[34] Ayers, J. and Dodman, D. (2010) Climate Change Adaptation and Development, I: The State of the Debate. Progress in Development Studies, 10, 161-168.

[35] Fankhauser, S. (2010) Market and Policy Driven Adaptation. In: Smart Solutions to Climate Change, Cambridge University Press, Cambridge.

[36] Fankhauser, S. and McDermott, T. (2014) Understanding the Adaptation Deficit: Why Are Poor Countries More Vulnerable to Climate Events than Rich Countries? Global Environmental Change, 27, 9-18. https://doi.org/10.1016/j.gloenvcha.2014.04.014

[37] Di Falco, S., Veronesi, M. and Yesuf, M. (2011) Does Adaptation to Climate Change Provide Food Security? A Micro-Perspective from Ethiopia. American Journal of Agricultural Economics, 93, 829-846. https://doi.org/10.1093/ajae/aar006

[38] Di Falco, S. and Veronesi, M. (2013) How Can African Agriculture Adapt to Climate Change? A Counterfactual Analysis from Ethiopia. Land Economics, 89, 743-766. https://doi.org/10.3368/le.89.4.743

[39] Petherick, A. (2012) Enumerating Adaptation. Nature Climate Change, 2, 228-229. https://doi.org/10.1038/nclimate1472

[40] Hertel, T. and Lobell, D. (2014) Agricultural Adaptation to Climate Change in Rich and Poor Countries: Current Modeling Practice and Potential for Empirical Contributions. Energy Economics, 46, 562-575. https://doi.org/10.1016/j.eneco.2014.04.014

[41] DeZeeuw, A. and Zemel, A. (2012) Regime Shifts and Uncertainty in Pollution Control. Journal of Economic Dynamics and Control, 36, 939-950. https://doi.org/10.1016/j.jedc.2012.01.006

[42] Zemel, A. (2015) Adaptation, Mitigation and Risk: An Analytic Approach. Journal 
of Economic Dynamics and Control, 51, 133-147.

https://doi.org/10.1016/j.jedc.2014.10.001

[43] Castells-Quintana, D., del Pilar Lopez-Uribe, M. and McDermott, T.K.J. (2018) Adaptation to Climate Change: A Review through a Development Economics Lens. World Development, 104, 183-196.

[44] Cai, H., Chen, Y., Fang, H. and Zhou, L. (2009) Microinsurance, Trust and Economic Development: Evidence from a Randomized Natural Field Experiment. NBER Working Paper No. 15396. National Bureau of Economic Research, Cambridge, MA. https://doi.org/10.3386/w15396

[45] Galarza, F. and Carter, M. (2011) Risk Preferences and Demand for Insurance in Peru: A Field Experiment. Working Paper No. 11-08. Universidad del Pacifico, Lima.

[46] Hill, R. and Viceisza, A. (2012) A Field Experiment on the Impact of Weather Shocks and Insurance on Risky Investment. Experimental Economics, 15, 341-371. https://doi.org/10.1007/s10683-011-9303-7

[47] Mubarak, A.M. and Rosenzweig, M.R. (2013) Informal risk sharing, index insurance, and risk taking in developing countries. American Economic Review, 103, 375-380. https://doi.org/10.1257/aer.103.3.375

[48] Hecht, S. (2008) Climate Change and the Transformation of Risk: Insurance Matters. UCLA Law Review, 55, 1559-1620.

[49] Ward, R., Herweijer, C., Patmore, N. and Muir-Wood, R. (2008) The Role of Insurers in Promoting Adaptation to the Impacts of Climate Change. The Geneva Papers, 33, 133-139. https://doi.org/10.1057/palgrave.gpp.2510153

[50] Munich Climate Insurance Initiative (MCII) (2012) Insurance Solutions in the Context of Climate Change-Related Loss and Damage: Needs, Gaps, and Roles of the Convention in Addressing Loss and Damage. Policy Brief No. 6. UNU-EHS Publication Series.

[51] Munich Climate Insurance Initiative (MCII) (2013) Climate Risk Adaptation and Insurance. Reducing Vulnerability and Sustaining the Livelihood of Low-Income Communities. Report No. 13. UNU-EHS Publication Series.

[52] Agrawala, S. and Carraro, M. (2010) Assessing the Role of Microfinance in Fostering Adaptation to Climate Change. OECD Environmental Working Paper No. 15. Organisation for Economic Co-operation and Development, Paris. https://doi.org/10.2139/ssrn.1646883

[53] Consulter le site.

http://www.banquemondiale.org/fr/news/press-release/2013/06/19/warmer-worldwill-keep-millions-of-people-trapped-in-poverty-says-new-report

[54] King, M. (2012) Is Mobile Banking Breaking the Tyranny of Distance to Bankinfrastructure? Evidence from Kenya. IIIS Discussion Paper No. 412. Institute for International Integration Studies, Dublin. 


\section{Appendix 1: Global Climate Finance Architecture}

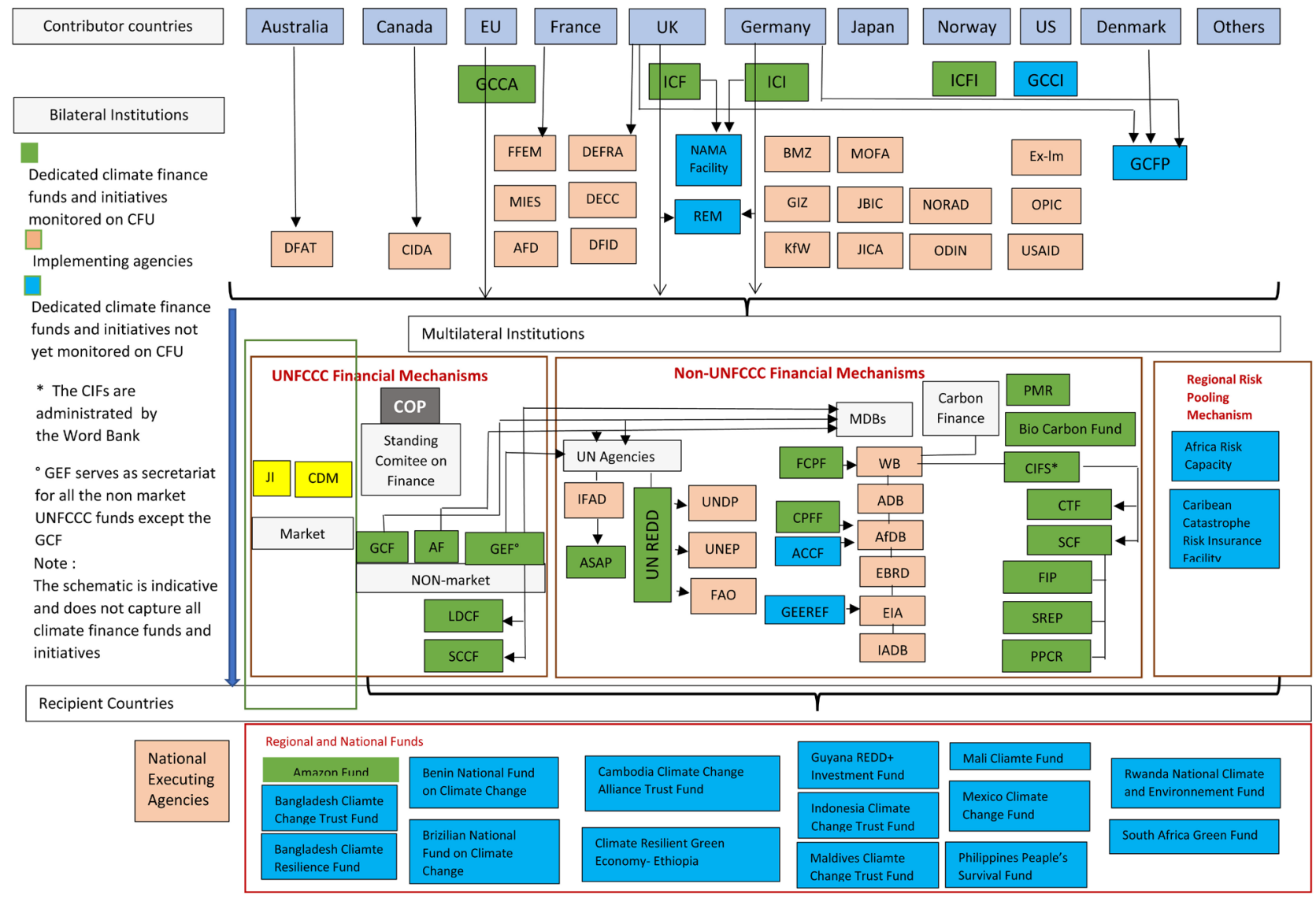

Source: Climate Finance Update

\section{Appendix 2: Public Financing Plan for the Noor Ouarzazate Complex (As Proposed in 2014)}

\begin{tabular}{|l|c|}
\hline Financeur public & Financement en Million USD \\
\hline Banque africaine de développement (BAD) & 135 \\
\hline Commission Européenne (CE) & 122 \\
\hline Banque Européenne d'Investissement (BEI) & 473 \\
\hline France: Agence française de développement (AFD) & 68 \\
\hline Banque internationale pour la reconstruction et le développement (BIRD) & 400 \\
\hline Allemagne: Banque Allemande de développement (kfw) & 884 \\
\hline Emprunteur: Gouvernement du Maroc/MASEN & 357 \\
\hline Fonds pour les technologies Propres (FTP) & 238 \\
\hline Engagement financier public total & 2677 \\
\hline
\end{tabular}

Source: http://www.worldbank.org/projects/p131256/?lang=en\&tab=financial; 30 Sept 2016. 


\section{Appendix 3: List of Climate Projects}

\begin{tabular}{|c|c|c|c|c|c|}
\hline Fund & Name of Project & $\begin{array}{l}\text { Theme/Objective } \\
\text { (mitigation, REDD+, } \\
\text { adaptation, } \\
\text { multiple-CFU } \\
\text { Categories) }\end{array}$ & $\begin{array}{l}\text { Approved } \\
\text { year }\end{array}$ & $\begin{array}{l}\text { Amount of } \\
\text { Funding } \\
\text { Approved } \\
\text { (\$millions) }\end{array}$ & $\begin{array}{r}\text { Disbursed } \\
\text { (\$millions) }\end{array}$ \\
\hline $\begin{array}{l}\text { Adaptation for Smallholder } \\
\text { Agriculture Program (ASAP) }\end{array}$ & $\begin{array}{l}\text { Programe de Development Rural } \\
\text { des Zones de Montagne (PDRZM) }\end{array}$ & Adaptation & 2014 & 2 & 0.009593 \\
\hline $\begin{array}{l}\text { Adaptation Fund } \\
\text { (AF) }\end{array}$ & $\begin{array}{c}\text { Climate changes adaptation } \\
\text { project in oasis zones - PACC-ZO }\end{array}$ & Adaptation & 2015 & 9.97 & 7.31 \\
\hline $\begin{array}{l}\text { Clean Technology Fund } \\
\text { (CTF) }\end{array}$ & Phase II of Midelt or Tata & Mitigation - general & 2017 & 25 & \\
\hline $\begin{array}{l}\text { Clean Technology Fund } \\
\text { (CTF) }\end{array}$ & Phase II of Midelt or Tata & Mitigation - general & 2017 & 25 & \\
\hline $\begin{array}{l}\text { Clean Technology Fund } \\
\text { (CTF) }\end{array}$ & Clean and Efficient Energy Project & Mitigation - general & 2014 & 24.75 & 0.76 \\
\hline $\begin{array}{l}\text { Clean Technology Fund } \\
\text { (CTF) }\end{array}$ & $\begin{array}{l}\text { Noor II and III Concentrated } \\
\text { Solar Power Project }\end{array}$ & Mitigation - general & 2014 & 238 & 238 \\
\hline $\begin{array}{l}\text { Clean Technology Fund } \\
\text { (CTF) }\end{array}$ & $\begin{array}{l}\text { Ouarzazate I Concentrated } \\
\text { Solar Power Project }\end{array}$ & Mitigation - general & 2012 & 197 & 197 \\
\hline $\begin{array}{l}\text { Clean Technology Fund } \\
\text { (CTF) }\end{array}$ & One Wind Energy Plan & Mitigation - general & 2011 & 125 & 20.3 \\
\hline $\begin{array}{l}\text { Global Environment Facility } \\
\text { (GEF4) }\end{array}$ & $\begin{array}{l}\text { Energy Efficiency Codes in Residential } \\
\text { Buildings and Energy Efficiency } \\
\text { Improvement in Commercial and } \\
\text { Hospital Buildings in Morocco }\end{array}$ & Mitigation - general & 2007 & 3 & 3 \\
\hline $\begin{array}{l}\text { Global Environment Facility } \\
\text { (GEF4) }\end{array}$ & $\begin{array}{l}\text { Energy Efficiency } \\
\text { in the Industrial Sector }\end{array}$ & Mitigation - general & 2010 & 2.73 & 2.73 \\
\hline $\begin{array}{l}\text { Global Environment Facility } \\
\text { (GEF4) }\end{array}$ & $\begin{array}{l}\text { Market Transformation for Energy } \\
\text { Efficient Lighting in Morocco }\end{array}$ & Mitigation - general & 2010 & 0.889091 & 0.889 \\
\hline $\begin{array}{l}\text { Global Environment Facility } \\
\text { (GEF5) }\end{array}$ & $\begin{array}{l}\text { Mainstreaming Climate Change in the } \\
\text { National Logistics Strategy and } \\
\text { Roll-Out of Integrated Logistics Platforms }\end{array}$ & Multiple foci & 2013 & 2.274429 & 2.27 \\
\hline $\begin{array}{l}\text { Global Environment Facility } \\
\text { (GEF5) }\end{array}$ & $\begin{array}{l}\text { Promoting the Development of } \\
\text { Photovoltaic Pumping } \\
\text { Systems for Irrigation }\end{array}$ & Mitigation - general & 2014 & 2.639726 & \\
\hline $\begin{array}{l}\text { Global Environment Facility } \\
\text { (GEF6) }\end{array}$ & $\begin{array}{l}\text { Greening COP22 in } \\
\text { Marrakesh, Morocco }\end{array}$ & Mitigation - general & 2016 & 1.826484 & 1.826484 \\
\hline $\begin{array}{l}\text { Global Environment Facility } \\
\text { (GEF6) }\end{array}$ & $\begin{array}{l}\text { Programme for Cleantech Innovation } \\
\text { and Green Jobs in Morocco }\end{array}$ & Mitigation - general & 2016 & 0.913242 & 0.913242 \\
\hline $\begin{array}{l}\text { Global Environment Facility } \\
\text { (GEF6) }\end{array}$ & $\begin{array}{l}\text { Renewable Energy for the City of } \\
\text { Marrakech's Bus Rapid Transit System }\end{array}$ & Mitigation - general & 2016 & 1.319863 & \\
\hline $\begin{array}{l}\text { Global Environment Facility } \\
\text { (GEF6) }\end{array}$ & $\begin{array}{l}\text { Second Biennial Updated Report } \\
\text { and Fourth National } \\
\text { Communication under the UNFCCC }\end{array}$ & Multiple foci & 2016 & 0.852 & \\
\hline Green Climate Fund (GCF) & (FP043) Saiss Water Conservation Project & Adaptation & 2017 & 37.6 & \\
\hline
\end{tabular}




\section{Continued}

Green Climate Fund
(GCF)
Green Climate Fund
(GCF)
Partnership for
Market Readiness
Partnership for
Market Readiness
Special Climate
Change Fund (SCCF)
Special Climate
Change Fund (SCCF)
Special Climate
Change Fund (SCCF)

(FP042) Irrigation development and adaptation of irrigated agriculture to climate change in semi-arid Morocco

(FP022) Development of Argan
Orchards in Degraded Environment

Market Readiness Proposal MRP

PMR Program Morocco

Enhancing the climate resilience of the Moroccan ports sector

Increasing Productivity and Adaptive Capacity in Mountain areas of Morocco (IPAC-MAM)

Integrating Climate Change in Development Planning and Disaster Prevention to Increase Resilience of Agricultural and Water Sectors

Adaptation $\quad 2017 \quad 23.5$

Multiple foci $\quad 2016 \quad 39.3$

Mitigation - general $2011 \quad 0.35$

Mitigation - general $2014 \quad 3$

Adaptation $\quad 2009 \quad 6.192694$

Adaptation $\quad 2014 \quad 6.51$

Adaptation $\quad 2014 \quad 4.345454 \quad 4.35$

Source: Climate Funds Update (CFU), https://climatefundsupdate.org/the-funds/. 